\title{
Inbreeding depression and average genetic components in green corn genotypes
}

\author{
Maurício Carlos Kuki ${ }^{*}$ Carlos Alberto Scapim² Ronald José Barth Pinto \\ Alex Sandro Torre Figueiredo ${ }^{1}$ Rodrigo Iván Contreras-Soto ${ }^{1}$ Filipe Augusto Bengosi Bertagna ${ }^{3}$
}

\author{
${ }^{1}$ Programa de Pós-graduação em Genética e Melhoramento (PGM), Universidade Estadual de Maringá (UEM), Maringá, PR, Brasil. E-mail: \\ mcarloskuki@gmail.com. .Corresponding author. \\ ${ }^{2}$ Departamento de Agronomia (DAG), Universidade Estadual de Maringá (UEM), Maringá, PR, Brasil. \\ ${ }^{3}$ Pós-graduação em Agronomia (PGA), Universidade Estadual de Maringá (UEM), Maringá, PR, Brasil.
}

\begin{abstract}
This study aimed to evaluate the inbreeding depression and average genetic components in seven hybrids and two open pollinated cultivars for green corn production, as well as to select the best genotypes in order to obtain base populations for inbred lines extraction. The experiment was carried out in a randomized complete block design with four replications, in a split plot design, with inbreeding levels arranged in the plots and the different genotypes distributed over the subplots, in the municipality of Sabáudia-PR, during the 2014/15 crop season. Higher values of dominance and inbreeding depression were observed for yield of both unhusked and commercial ears. Higher additive effects were detected on length and diameter of commercial ears. The genotypes AM811, Cativerde 02 and AG4051 showed greater probability of obtaining highly productive and higher quality green corn inbred lines.
\end{abstract}

Key words: in nature corn, loss of vigor, genetic effects.

Depressão por endogamia e componentes genéticos de médias em genótipos de milho verde

RESUMO: O trabalho teve por objetivo avaliar a depressão por endogamia e os componentes genéticos de médias em sete híbridos e em duas variedades de polinização aberta para uso como milho verde, para seleção de genótipos visando à formação de populações-base para a extração de linhagens. Para a realização do estudo, foi instalado um experimento no município de Sabáudia - PR, no ano agrícola de $2014 / 15$. $O$ experimento foi delineado em blocos completos ao acaso, com quatro repetições, em arranjo de parcelas subdivididas, com as gerações de endogamia e os diferentes genótipos ocupando as parcelas e as subparcelas, respectivamente. As maiores estimativas de dominância e de depressão endogâmica foram observadas na produtividade de espigas empalhadas e comerciais. Os efeitos aditivos foram mais expressivos na herança do comprimento e do diâmetro de espigas comerciais. Os genótipos AM811, Cativerde 02 e AG4051 apresentaram maiores probabilidades no sucesso de extração de linhagens destinadas à produtividade e qualidade de milho verde.

Palavras-chave: milho in natura, perda de vigor, efeitos gênicos.

\section{INTRODUCTION}

Maize is considered the most studied allogamous species due to its great social and economic importance (GRIGULO et al., 2011). Among the multiple plant products derived from corn, green corn production is of great commercial importance (MATOS, 2007). Green corn can be used in the food industry or for in natura consumption, raising the economic value of the final product and incentivizing farmers to increase their yield (DOVALE et al., 2011).

For a maize genotype to qualify as green corn for use in the food industry or consumption in natura, it must have a yield of unhusked ears higher than 12 t.ha ${ }^{-1}$, a production cycle (seedharvest period) between 90-110 days, a commercial ear length greater than $15 \mathrm{~cm}$ and a diameter larger than $3 \mathrm{~cm}$ (ALBUQUERQUE et al., 2008). Thus, there is a preference for dent corn genotypes with grain color between cream and yellow, absence of pest damage, large hulled ears and straight rows (CANCELLIER et al., 2011).

In allogamous plant breeding programs, it is essential to generate base populations that can be used in the future as a source of inbred lines for obtaining superior hybrids (HALLAUER et al., 2010). However, the selection of the best populations should be based on genetic parameters related to the following factors: behavior of inbred lines when 
they reach complete homozygosity, highlighting, inbreeding depression (ID), estimated additive effects $(\mu+\alpha)$ and the contribution of heterozygous loci $(\delta)$ (VENCOVSKY \& BARRIGA, 1992). Current corn breeding programs have opted to use commercial hybrids to generate base populations due to the high degree of breeding of these genotypes, their adaptation to cultivation conditions and the presence of favorable alleles for traits of interest.

The reduction of the adaptive value of a genotype derived from the crossing of related genotypes is called "inbreeding depression", and it depends on the frequency of deleterious recessive alleles involved in the trait control (FREITAS et al., 2016).

The per se value of a completely endogamic inbred line may be predicted from the performance of the $F_{1}$ generation from which it is originated. After infinite self-fertilization, the phenotype of the inbred line, $S_{\infty}$, will be the result of the average $\left(F_{1}\right)$ and additive effects, since dominance deviations will be extinguished during successive self-fertilizations.

Several authors support the efficacy of the expected pure inbred lines methodology, as well as inbreeding depression, in predicting the breeding potential of segregating populations based on maize forage quality, grain yield and popcorn quality (SCAPIM et al. 2006; ARNHOLD et al., 2010; BERNINI et al., 2013; SOUZA NETO et al., 2015). However, there is no literature related to the deleterious effects of inbreeding depression on green corn production and quality characteristics.

The objectives of this study were to estimate the effects of inbreeding depression and the average genetic components of nine maize genotypes on their green corn potential with the aim of identifying promising genotypes for the extraction of inbred lines for the maize breeding program.

\section{MATERIALS AND METHODS}

The $\mathrm{S}_{0}$ and $\mathrm{S}_{1}$ generations were evaluated from nine maize genotypes (Table 1), seven of which have green corn aptitude and two of which have aptitude exclusively for grains. The $\mathrm{S}_{1}$ generation was obtained from a manually pollinated field in the second growing season of 2014. The genotypes were planted in four, 10-meter long rows spaced $0.9 \mathrm{~m}$ apart, and 250-300 ears from each $\mathrm{S}_{0}$ genotype were manually self-pollinated.

The experiment with the $\mathrm{S}_{0}$ and $\mathrm{S}_{1}$ genotypes was conducted in the municipality of Sabáudia, PR (23ำ'S, $51^{\circ} 33^{\prime} \mathrm{W}$; altitude: $\left.725 \mathrm{~m}\right)$, in the first growing season of 2014/2015. According to the Köppen classification, the climate of the region is $\mathrm{Cfa}$ with an annual average temperature of $19^{\circ} \mathrm{C}$ and an annual rainfall of $1500 \mathrm{~mm}$. The experiment was arranged in a split-plot randomized block design with four replications; the two endogamic generations $\left(\mathrm{S}_{0}\right.$ and $S_{1}$ ) were assigned to the plots, and the nine green corn genotypes were assigned to the subplots. Subplots consisted of four 5-meter long rows spaced 0.9 meters apart; the sampled area was the two central rows.

Sowing was performed on 11/29/2014; fertilization consisted of $250 \mathrm{~kg} \mathrm{ha}^{-1}$ of $08-20-20 \mathrm{NPK}$ fertilizer, and side-dressing fertilization was applied as $50 \mathrm{~kg} \mathrm{ha}^{-1}$ of urea when plants were at the V6 stage. At 45 days after plant emergence, a thinning operation was performed to adjust the stand to 55.555 plants ha ${ }^{-1}$.

Table 1 - Characteristics of the evaluated genotypes, according to genetic base, cycle, company, type and color of grain, and aptitude production at Sabáudia - PR.

\begin{tabular}{|c|c|c|c|c|c|c|}
\hline Genotype & Genetic Base & Cycle & Company & Type of grain & Color of grain & Aptitude \\
\hline AG 1051 & $\mathrm{DH}^{1}$ & $\mathrm{SME}^{5}$ & Agroeste & Dent & Yellow & $\mathrm{G}^{10} / \mathrm{S}^{11} / \mathrm{GC}^{12}$ \\
\hline AG 4051 & $\mathrm{TH}^{2}$ & SME & Agroeste & Dent & Y/Cream ${ }^{7}$ & $\mathrm{G} / \mathrm{S} / \mathrm{GC}$ \\
\hline AL Pirat. & $\mathrm{OPC}^{3}$ & SME & CATI & Semident & Y/Orange $^{8}$ & $\mathrm{G} / \mathrm{S} / \mathrm{GC}$ \\
\hline Cativ. 02 & OPC & SME & CATI & Dent & Yellow & $\mathrm{S} / \mathrm{GC}$ \\
\hline CD 316 & $\mathrm{SH}^{4}$ & $\mathrm{VE}^{6}$ & Coodetec & Semi flint & Yellow & G \\
\hline CD 393 & $\mathrm{SH}$ & VE & Coodetec & Flint & Orange & G \\
\hline AM 606 & $\mathrm{SH}$ & VE & M.A. ${ }^{13}$ & Semi flint & Orange & $\mathrm{G} / \mathrm{S} / \mathrm{GC}$ \\
\hline AM 811 & $\mathrm{SH}$ & $\mathrm{VE}$ & M.A. & Semident & Orange & $\mathrm{G} / \mathrm{S} / \mathrm{GC}$ \\
\hline HTMV1 & TH & SME & Embrapa & Semident & Yellow & $\mathrm{G} / \mathrm{S} / \mathrm{GC}$ \\
\hline
\end{tabular}

${ }^{1} \mathrm{DH}$ : double hybrid, ${ }^{2} \mathrm{TH}$ : triple hybrid, ${ }^{3} \mathrm{OP}$ : open pollinated cultivar, ${ }^{4} \mathrm{SH}$ : simple hybrid, ${ }^{6} \mathrm{VE}$ : very early, ${ }^{5} \mathrm{SME}$ : Semi early, ${ }^{7} \mathrm{Y} / \mathrm{Cream}$ : yellow cream, ${ }^{8} \mathrm{Y} /$ Orange: yellow orange, ${ }^{10} \mathrm{G}$ : grain production, ${ }^{11} \mathrm{~S}$ : silage production, ${ }^{12} \mathrm{GC}$ : green corn production, ${ }^{13} \mathrm{Melhoramento}$ Agropastoril. 
Green corn harvesting and the evaluation of the quality characteristics began at the R3 stage (kernel milk) when the moisture content was between 70 to $80 \%$ and was preferably conducted at times of the day with mild temperatures.

The following variables were evaluated: female flowering (FF, days); average plant height $(\mathrm{PH}, \mathrm{cm})$ and average ear insertion height $(\mathrm{EH}, \mathrm{cm})$ of six competitive plants; yield of unhusked ears (YU, $\left.\mathrm{kg} \mathrm{ha}^{-1}\right)$; yield of commercial ears ( $\left.\mathrm{YC}, \mathrm{kg} \mathrm{ha}^{-1}\right)$; grain mass of five commercial ears (GM, g) corrected to a moisture content of $75 \%$; average length (LE, $\mathrm{cm}$ ) and diameter (DE, $\mathrm{mm}$ ) of ten commercial ears; grain color (GC) of five commercial ears, according to the scale proposed by ALBUQUERQUE et al. (2008); and alignment of rows (AR) of five commercial ears, which ranged from a score of 1 for straight rows to 5 for the complete lack of row alignment.

The data were subjected to analysis of variance at a $5 \%$ probability level. Inbreeding depression (\%) was estimated using the per se genotype average and the average of the resultant $\mathrm{S}_{1}$ populations according to the equation $\mathrm{DE}=-\mathrm{x} 100$, in which $\mathrm{S}_{0}$ is the average of the original genotype, and $\mathrm{S}_{1}$ is the average of the population after one self-pollinated generation. The potential of each genotype as a source of endogamic lines from the expected means of the inbred lines $(\mu$ $+\alpha$ ) and the contribution of the heterozygous loci $(\delta)$ were estimated from the equations suggested by VENCOVSKY \& BARRIGA (1992).

\section{RESULTS AND DISCUSSION}

Significant differences were observed in all of the evaluated traits (Table 2). The significant effects of the interaction between inbreeding depression (ID) and genotype on YU, YC, GM, LE and DE showed that ID intensity differed among the genotypes. For $\mathrm{PH}$ and GC, the effects of the primary and secondary treatments were significant, but the interaction among factors was not significant, therefore, the inbred generations $\left(\mathrm{S}_{0}\right.$ and $\left.\mathrm{S}_{1}\right)$ acted independently from the genotype. For FF, EH and AR, the primary effect was not significant, so it was impossible to detect ID in these traits after at least one generation of inbreeding.

The estimated ID values varied among genotypes and traits, which should be a consequence of the reduced number of heterozygous loci $(\delta)$ and the expression of deleterious recessive alleles resulting in self-fertilization. VENCOVSKY \& BARRIGA (1992) emphasized that the base populations selected for the extraction of inbred lines should exhibit a high frequency of favorable alleles and a low frequency, or low expression, of negative alleles. Thus, estimates of inbreeding depression are associated with the frequencies recessive alleles and the loss of vigor that they provoke in their carriers.

For LE, the estimated ID values varied from 4.66 (Cativerde 02) to $13.44 \%$ (AM606). For DE, these values ranged from 1.58 (AM811) to $6.84 \%$ (Al Piratininga), and for $\mathrm{PH}$ and GC, the average ID value was $6.89 \%$ and $7.63 \%$, respectively. Similar results were reported by SCAPIM et al. (2006) and ARNHOLD et al. (2010) in popcorn populations and hybrids, and BERNINI et al. (2013) observed levels of ID ranging from 5.5 to $13 \%$ for plant height and 0.8 to $8.6 \%$ for ear height in commercial hybrids of common maize.

For the traits related to green corn productivity, levels of inbreeding depression varied from 9.28 (AG4051) to 37.40\% (AM606) for YU, $16.38 \%$ (AM811) to $41.32 \%$ (AM606) for YC and $19.36 \%$ (Cativerde 02) to $37.23 \%$ (AM606) for GM. These results agree with previous findings for maize productivity and grain yield (SCAPIM et al., 2006; BERNINI et al., 2013), and KOUTSIKA-SOTIRIOU \& KARAGOUNIS (2005) verified low estimates of inbreeding depression in the commercial hybrid Prezia compared with Constanza and Nubia hybrids in terms of grain yield, with ID values of $28.9 \%$, $44.3 \%$ and $54.7 \%$, respectively.

LIMA et al. (1984) associated low values of inbreeding depression with the low participation of dominance genetic effects (deviations) in the expression of some traits. For quantitative traits, the contribution of heterozygous loci is high, so there is a tendency toward increased inbreeding depression (ARNHOLD et al., 2010; FREITAS et al., 2016). In the present study, characteristics that showed inheritance with the highest dominance effect had high estimated inbreeding depression, indicating the importance of dominant gene action as a factor in inbreeding depression.

According to VENCOVSKY \& BARRIGA (1992), when $S_{1}$ is not superior to the $\mathrm{S}_{0}$ generation, the estimates of $\mu+\alpha$ allow breeders to more accurately select genotypes based on these genetic components. Thus, when the ID is lower in the population, the influence of dominant effects on the means is lower, so the estimates of $\mu+\alpha$ will be higher (CRUZ et al., 2012).

Higher means from the expected inbred lines expected for YU and $\mathrm{YC}$ were observed with genotypes AG4051 and AM811, and for GM, the AM811 and Cativerde 02 genotypes were superior. For LE, DE, $\mathrm{PH}$ and $\mathrm{EH}$, genotypes with the higher estimates were AM811, A1Piratininga and Cativerde 02. 
Table 2 - P-values, $\mathrm{S}_{0}$ and $\mathrm{S}_{1}$ means, inbreeding depression (ID \%), contribution of the heterozygous loci $(\delta)$ and expected pure inbred lines means $(\mu+\alpha)$ for the variables related to green corn at Sabáudia-PR, 2015.

\begin{tabular}{|c|c|c|c|c|c|c|c|c|c|c|c|}
\hline & \multicolumn{2}{|c|}{$\mathrm{FF}^{1}$} & $\mathrm{YU}^{2}$ & $\mathrm{YC}^{3}$ & $\mathrm{GM}^{4}$ & $\mathrm{LE}^{5}$ & $\mathrm{DE}^{6}$ & $\mathrm{PH}^{7}$ & $\mathrm{EH}^{8}$ & $\mathrm{GC}^{9}$ & $\mathrm{AR}^{10}$ \\
\hline Endogamy & \multicolumn{2}{|c|}{$0.2522^{\mathrm{ns}}$} & $0.0013^{*}$ & $0.0005^{*}$ & $0.0239^{*}$ & $0.0015^{*}$ & $0.0048^{*}$ & $0.0239^{*}$ & $0.6430^{\mathrm{ns}}$ & $0.0034^{*}$ & $0.6110^{\text {ns }}$ \\
\hline Genotype & \multicolumn{2}{|c|}{$0.0000^{*}$} & $0.0000^{*}$ & $0.0000^{*}$ & $0.0002^{*}$ & $0.0200^{*}$ & $0.0000^{*}$ & $0.0000^{*}$ & $0.0000^{*}$ & $0.0000^{*}$ & $0.0002^{*}$ \\
\hline \multirow[t]{3}{*}{ End $x$ Gen } & \multicolumn{2}{|c|}{$0.9990^{\mathrm{ns}}$} & $0.0154^{*}$ & $0.0410^{*}$ & $0.0156^{*}$ & $0.0014^{*}$ & $0.0340^{*}$ & $0.5532^{\mathrm{ns}}$ & $0.2659^{\mathrm{ns}}$ & $0.3953^{\mathrm{ns}}$ & $0.5984^{\mathrm{ns}}$ \\
\hline & $\mathrm{S}_{0}$ & 57.5 & 18886.1 & 11449.4 & 0.906 & 20.01 & 49.39 & 186.45 & 94.79 & 3.8 & 2.05 \\
\hline & $\mathrm{S}_{1}$ & 58 & 11822.2 & 6718.06 & 0.569 & 17.40 & 46.21 & 172.08 & 98.54 & 3.55 & 2.1 \\
\hline \multirow[t]{5}{*}{ AM606 } & $\mathrm{DE}$ & -0.87 & 37.40 & 41.3 & 37.23 & 13.04 & 6.43 & 7.71 & 3.96 & 6.6 & -2.44 \\
\hline & $\delta$ & -1 & 14127.7 & 9462.7 & 0.675 & 5.22 & 6.35 & 28.75 & 7.5 & 0.5 & -0.1 \\
\hline & $\mu+\alpha$ & 58.5 & 4758.3 & 1986.7 & 0.231 & 14.8 & 43.04 & 157.71 & 102.2 & 3.3 & 2.15 \\
\hline & $\mathrm{S}_{0}$ & 59.5 & 16780.6 & 10069.4 & 1.021 & 19.5 & 50.23 & 206.66 & 116.41 & 3.85 & 2.4 \\
\hline & $\mathrm{S}_{1}$ & 59.5 & 15091.7 & 8369.44 & 0.818 & 17.6 & 49.93 & 200.83 & 110.45 & 3.85 & 2.45 \\
\hline \multirow[t]{5}{*}{ AM811 } & $\mathrm{DE}$ & 0 & 10.1 & 16.9 & 19.88 & 10.6 & 1.58 & 2.82 & 5.47 & 0 & -2.08 \\
\hline & $\delta$ & 0 & 3377.8 & 3400 & 0.406 & 3.76 & 1.57 & 11.67 & 12.08 & 0 & -0.1 \\
\hline & $\mu+\alpha$ & 59.5 & 13.402 .8 & 6669.4 & 0.615 & 21.43 & 51.51 & 195 & 122.5 & 3.9 & 2.50 \\
\hline & $\mathrm{S}_{0}$ & 61 & 17891.7 & 11047.2 & 0.977 & 21.01 & 51.49 & 203.12 & 114.79 & 3.4 & 2.4 \\
\hline & $\mathrm{S}_{1}$ & 61 & 13355.6 & 7640.28 & 0.760 & 19.02 & 48.13 & 196.25 & 113.75 & 2.7 & 2.35 \\
\hline \multirow[t]{5}{*}{ HTMV1 } & $\mathrm{DE}$ & 0 & 25.4 & 30.8 & 22.21 & 9.46 & 6.53 & 3.38 & 0.91 & 20.6 & 2.08 \\
\hline & $\delta$ & 0 & 9072.2 & 6813.9 & 0.434 & 3.98 & 6.73 & 13.75 & 2.08 & 1.4 & 0.1 \\
\hline & $\mu+\alpha$ & 61 & 8819.4 & 4233.3 & 0.543 & 17.04 & 44.77 & 189.38 & 112.71 & 2 & 2.3 \\
\hline & $\mathrm{S}_{0}$ & 59.5 & 14263.9 & 8258.33 & 0.657 & 20.01 & 47.75 & 225.83 & 130.20 & 3 & 2.15 \\
\hline & $\mathrm{S}_{1}$ & 60 & 9830.56 & 5535.56 & 0.513 & 18.30 & 44.48 & 220.41 & 130.62 & 2.55 & 2.5 \\
\hline \multirow[t]{5}{*}{ AL PR. } & $\mathrm{DE}$ & -0.84 & 31.1 & 33.0 & 21.79 & 8.54 & 6.84 & 2.4 & -0.32 & 15 & -16.2 \\
\hline & $\delta$ & -1 & 8866.7 & 5445.6 & 0.286 & 3.42 & 6.53 & 10.83 & -0.83 & 0.9 & -0.7 \\
\hline & $\mu+\alpha$ & 60.5 & 5397.2 & 2812.8 & 0.370 & 16.59 & 41.22 & 215 & 131.04 & 2.1 & 2.85 \\
\hline & $\mathrm{S}_{0}$ & 61 & 13741.7 & 8330.56 & 0.717 & 19.44 & 46.81 & 235.41 & 137.91 & 2.05 & 2.3 \\
\hline & $\mathrm{S}_{1}$ & 62 & 11186.1 & 6034.72 & 0.578 & 18.54 & 45.05 & 220.62 & 134.79 & 1.9 & 2.3 \\
\hline \multirow[t]{5}{*}{ CAT 02} & $\mathrm{DE}$ & -1.64 & 18.6 & 27.6 & 19.36 & 4.66 & 3.75 & 6.28 & 2.27 & 7.3 & 0 \\
\hline & $\delta$ & -2 & 5111.1 & 4591.7 & 0.277 & 1.81 & 3.52 & 29.58 & 6.25 & 0.3 & 0 \\
\hline & $\mu+\alpha$ & 63 & 8630.6 & 3738.9 & 0.439 & 17.63 & 43.29 & 205.83 & 131.6 & 1.8 & 2.3 \\
\hline & $\mathrm{S}_{0}$ & 55.5 & 16341.7 & 11424.3 & 0.900 & 19.10 & 47.67 & 213.54 & 111.45 & 4.35 & 2.1 \\
\hline & $\mathrm{S}_{1}$ & 55.5 & 10508.3 & 7026.39 & 0.606 & 17.86 & 45.07 & 185 & 102.70 & 3.8 & 2.1 \\
\hline \multirow[t]{5}{*}{ CD316 } & $\mathrm{DE}$ & 0 & 35.7 & 38.5 & 32.65 & 6.49 & 5.44 & 13.37 & 7.85 & 12.6 & 0 \\
\hline & $\delta$ & 0 & 11666.7 & 8795.8 & 0.587 & 2.48 & 5.19 & 57.08 & 17.5 & 1.1 & 0 \\
\hline & $\mu+\alpha$ & 55.5 & 4675 & 2628.5 & 0.312 & 16.63 & 42.48 & 156.46 & 93.96 & 3.3 & 2.10 \\
\hline & $\mathrm{S}_{0}$ & 59.5 & 15994.4 & 9225.0 & 0.785 & 20.13 & 46.00 & 217.5 & 114.16 & 4.75 & 2.05 \\
\hline & $\mathrm{S}_{1}$ & 59.5 & 12430.6 & 6468.06 & 0.562 & 18.36 & 43.21 & 197.70 & 103.95 & 4.2 & 2.05 \\
\hline \multirow[t]{5}{*}{ CD393 } & $\mathrm{DE}$ & 0 & 22.3 & 29.9 & 28.33 & 8.79 & 6.05 & 9.1 & 8.94 & 11.6 & 0 \\
\hline & $\delta$ & 0 & 7127.8 & 5513.9 & 0.445 & 3.54 & 5.56 & 39.58 & 20.42 & 1.1 & 0 \\
\hline & $\mu+\alpha$ & 59.5 & 8866.7 & 3711.1 & 0.340 & 16.6 & 40.44 & 177.92 & 93.75 & 3.7 & 2.05 \\
\hline & $\mathrm{S}_{0}$ & 61.5 & 12450.0 & 7997.22 & 0.891 & 20.43 & 49.00 & 226.45 & 122.29 & 2.6 & 2.5 \\
\hline & $\mathrm{S}_{1}$ & 61 & 10727.8 & 6727.78 & 0.608 & 18.07 & 48.04 & 221.04 & 132.08 & 2.5 & 2.75 \\
\hline \multirow[t]{5}{*}{ AG1051 } & $\mathrm{DE}$ & 0 & 38.1 & 39.0 & 23.19 & 7.08 & 3.38 & 8.3 & 11.94 & 21.9 & 12.7 \\
\hline & $\delta$ & 0 & 13205.6 & 8611.1 & 0.367 & 2.76 & 3.36 & 40 & 35.83 & 1.4 & 0.8 \\
\hline & $\mu+\alpha$ & 61 & 4125 & 2422.2 & 0.424 & 16.7 & 46.6 & 201.04 & 114.17 & 1.8 & 2.35 \\
\hline & $\mathrm{S}_{0}$ & 61.5 & 12450.0 & 7997.22 & 0.891 & 20.43 & 49 & 226.45 & 122.29 & 2.6 & 2.5 \\
\hline & $\mathrm{S}_{1}$ & 61.5 & 11294.4 & 6175.0 & 0.645 & 19 & 47.02 & 206.87 & 113.12 & 3.3 & 2.15 \\
\hline \multirow[t]{3}{*}{ AG4051 } & $\mathrm{DE}$ & 0 & 9.3 & 22.8 & 27.64 & 6.98 & 4.05 & 8.65 & 7.5 & -26.9 & 14 \\
\hline & $\delta$ & 0 & 2311.1 & 3644.4 & 0.492 & 2.85 & 3.97 & 39.17 & 18.33 & -1.4 & 0.7 \\
\hline & $\mu+\alpha$ & 61.5 & 10138.9 & 4352.8 & 0.398 & 17.58 & 45.03 & 187.29 & 103.96 & 4.0 & 1.8 \\
\hline
\end{tabular}

${ }^{1} \mathrm{FF}$ - Female flowering (days); ${ }^{2} \mathrm{YU}$ - Yield of unhusked ears $\left(\mathrm{kg} \cdot \mathrm{ha}^{-1}\right) ;{ }^{3} \mathrm{YC}$ - Yield of commercial ears $\left(\mathrm{kg}\right.$ ha $\left.{ }^{-1}\right) ;{ }^{4} \mathrm{GM}-\mathrm{Grain}$ mass $(\mathrm{g})$; ${ }^{5} \mathrm{LE}$ - Length (cm); ${ }^{6} \mathrm{DE}$ - Diameter $(\mathrm{mm}),{ }^{7} \mathrm{PH}$ - Plant height $(\mathrm{cm}),{ }^{8} \mathrm{EH}$ - Ear height $(\mathrm{cm}),{ }^{9} \mathrm{GC}$ - Grain color, ${ }^{10} \mathrm{AR}-\mathrm{Alignment}$ of rows. 
The estimates of $\delta$ allow the effects of heterozygous loci on the analyzed traits to be verified, so this parameter is used to indicate the variability among genotypes (CRUZ et al., 2012). Thus, the most promising genotypes for use in the extraction of lines should exhibit high values of $\mu+$ and high estimates of $\delta$, which will yield different lines with high means for important agronomic traits.

Across all the studied genotypes, the percentage of heterozygous loci was higher for YU, YC and GM. In maize, the presence of genetic dominance effects on grain yield was previously discussed by SCAPIM et al. (2006) and BERNINI et al. (2013). More specifically, for YU, YC and GM, the AM606, CD316 and AG1051 genotypes generated higher $\delta$ estimates, and for GM and LE, the AM811 genotype yielded desirable $\mu+\alpha$ and $\delta$ estimates. In terms of estimating the most suitable source of inbred lines, the lack of genotypes associated with these estimates reflects the difficulty in describing the genetic variability of a population (COCKERHAM, 1983).

In the present study, the genotypes were separated into groups to enable the comparison of genotypes with different genetic backgrounds (Table 3). For traits related to green corn productivity (YU, YC and GM), the estimate of inbreeding depression was higher for simple hybrids. This result was predictable given the importance of the non-additive genetic effects that control the inheritance of polygenic traits as well as the role of genic complementation in the heterotic expression observed in simple hybrids. The ID results obtained in the present study are consistent with the variation in ID in other studies of grain yield (BERNINI et al., 2013; SENHORINHO et al., 2015) and silage (SOUZA NETO et al., 2015).

Lower estimates of inbreeding depression are expected in genotypes with a high degree of genetic improvement because there is a low frequency of recessive alleles, which results in the loss of vigor. However, the variation in ID among different genetic backgrounds is also related to the different levels of dominance, allelic frequencies, and degree of relatedness among the genotypes (HALLAUER et al., 2010).

Based on the estimates of $\mu+\alpha$ and the contribution of heterozygous loci, the simple and triple hybrids showed superior green corn productivity traits, and this can be attributed to the high frequency of favorable alleles in the commercial genotypes that accumulated over several breeding cycles as well as the different cultivation conditions. Simple and triple hybrids represent an excellent alternative for the generation of base populations in breeding programs (SENHORINHO et al., 2015).

\section{CONCLUSION}

The genotypes AM811, Cativerde 02 and AG4051 showed the lowest values of inbreeding depression, specifically for productivity of unhusked and commercial ears. These genotypes also showed the best probability of success into the generation of inbred lines destined for yield and quality in green corn.

Table 3 - Inbreeding depression (ID), contribution of the heterozygous loci $(\delta)$ and the expected pure inbred lines means $(\mu+\alpha)$ in three distinct genetic base, for the variables related to green corn at Sabáudia-PR, 2015.

\begin{tabular}{lcccccccccccc}
\hline & $\mathrm{GB}$ & $\mathrm{FF}^{1}$ & $\mathrm{YU}^{2}$ & $\mathrm{YC}^{3}$ & $\mathrm{GM}^{4}$ & $\mathrm{LE}^{5}$ & $\mathrm{DE}^{6}$ & $\mathrm{PH}^{7}$ & $\mathrm{EH}^{8}$ & $\mathrm{GC}^{9}$ & $\mathrm{AR}^{10}$ \\
\hline $\mathrm{ID}$ & $\mathrm{SH}^{11}$ & -0.22 & 26.36 & 31.65 & 29.52 & 9.73 & 4.87 & 8.25 & 4.58 & 7.70 & 1.13 \\
$\mathrm{ID}$ & $\mathrm{TH}^{12}$ & 0 & 17.32 & 26.81 & 24.92 & 8.22 & 5.29 & 6.02 & 4.20 & -3.17 & 8.04 \\
\hline $\mathrm{ID}$ & $\mathrm{OPC}$ & -1.24 & 24.84 & 30.26 & 20.58 & 6.60 & 5.30 & 4.34 & 0.97 & 11.16 & 8.14 \\
\hline$\delta$ & $\mathrm{SH}$ & -0.25 & 9074.99 & 6793.12 & 0.53 & 3.75 & 4.67 & 34.27 & 10.63 & 0.67 & 0.05 \\
\hline$\delta$ & $\mathrm{HT}$ & 0 & 5691.67 & 5229.17 & 0.46 & 3.41 & 5.35 & 26.46 & 10.21 & 0 \\
\hline$\delta$ & $\mathrm{OPC}$ & -1.5 & 6988.89 & 5018.61 & 0.28 & 2.62 & 5.02 & 20.21 & 2.71 & 0.4 \\
\hline$\mu+\alpha$ & $\mathrm{SH}$ & 58.25 & 7925.70 & 3748.93 & 0.37 & 17.36 & 44.37 & 171.77 & 103.13 & 3.51 & 2.3 \\
\hline$\mu+\alpha$ & $\mathrm{TH}$ & 61.25 & 9479.17 & 4293.06 & 0.47 & 17.31 & 44.90 & 188.33 & 108.33 & 3 \\
\hline$\mu+\alpha$ & $\mathrm{OPC}$ & 61.75 & 7013.89 & 3275.83 & 0.41 & 17.11 & 42.26 & 210.42 & 131.35 & 1.92 & 2.05 \\
\hline
\end{tabular}

${ }^{1} \mathrm{FF}$ - Female flowering (days); ${ }^{2} \mathrm{YU}$ - Yield of unhusked ears $\left(\mathrm{kg} \mathrm{ha}^{-1}\right) ;{ }^{3} \mathrm{YC}-$ Yield of commercial ears $\left(\mathrm{kg} \mathrm{ha}{ }^{-1}\right) ;{ }^{4} \mathrm{GM}-\mathrm{Grain}$ mass $(\mathrm{g})$; ${ }^{5} \mathrm{LE}$ - Length (cm); ${ }^{6} \mathrm{DE}$ - Diameter $(\mathrm{mm}),{ }^{7} \mathrm{PH}$ - Plant height $(\mathrm{cm}),{ }^{8} \mathrm{EH}$ - Ear height $(\mathrm{cm}),{ }^{9} \mathrm{GC}-\mathrm{Grain}$ color, ${ }^{10} \mathrm{AR}-\mathrm{Alignment}$ of rows, ${ }^{11} \mathrm{SH}$ : Simple hybrid, ${ }^{12} \mathrm{TH}$ : Triple hybrid, ${ }^{13} \mathrm{OPC}$ : Open pollinated cultivar. 


\section{REFERENCES}

ALBUQUERQUE, C.J.B. et al. Produtividade de híbridos de milho verde experimentais e comerciais. Bioscience Journal, v.24. n.2. p.69-75, 2008. Available from: $<$ scielo.br/scielo.php?script=sci_ar ttext\&pid=S1413-70542008000300010>. Accessed: Jul. 12, 2015. doi: $10.1590 / \mathrm{S} 1413-70542008000300010$.

ARNHOLD, E. et al. Inbreeding depression and genetic components for popping expansion and other traits in Brazilian populations of popcorn. Ciencia e Investigación Agraria, v.37, n.3, p.125-132, 2010. Available from: <scielo-test.scielo.cl/scielo. php?script $=$ sci_arttext\&pid=S07186202010000300011\&lng= en\&nrm=iso >. Accessed: Mar. 23, 2015. doi: 10.4067/S071816202010000300011 .

BERNINI, C.S. et al. Depressão endogâmica e heterose de híbridos de populações F2 de milho no estado de São Paulo. Bragantia, v.72, p.217-223-223, 2013. Available from: <http:// dx.doi.org/10.1590/brag.2013.038>. Accessed: Jul. 08, 2015. doi: 10.1590/brag.2013.038

CANCELLIER, L.L. et al. Desempenho de populações de milho para produção de grãos e consumo in natura no Estado de Tocantins. Revista Ciência Agronômica, v.42, n.2, p.542-553, 2011. Available from: $<$ scielo.br/scielo.php?script $=$ sci_arttext\&p id=S1806-66902011000200038 $>$. Accessed: Mar. 28, 2015. doi: 10.1590/S1806-66902011000200038.

CRUZ, C.D. et al. Modelos biométricos aplicados ao melhoramento genético. Viçosa: UFV, 2012. 514 p.

COCKERHAM, C.C. Covariances of relatives from selffertilization. Crop Science, v.23, p.1177-1180, 1983. Available from: <dl.sciencesocieties.org/publications/cs/abstracts/23/6/CS0 230061177 .access $=0 \& v i e w=p d f>$. Accessed: Aug. 04, 2015. doi: 10.2135/cropsci1983.0011183X002300060035x.

FREITAS, J.P.X. et al. Inbreeding depression in cassava for productive traits. Euphytica, v.208, p.1-9, 2016. Available from: $<$ http://dx.doi.org/10.1007/s10681-016-1649-7>. Accessed: Mar. 23, 2015. doi: 10.1007/s10681-016-1649-7.

DOVALE, J.C. et al. Índice de seleção para cultivares de milho com dupla aptidão: minimilho e milho verde. Bragantia, v.70. n.4. p.781-787, 2011. Available from: <www.scielo.br/scielo.php ?pid=S000687052011000400008\&script $=$ sci abstract\&tlng $=$ pt $>$. Accessed: Jun. 22, 2015. doi: 10.1590/S0006-87052011000400008.

GRIGULO, A.S.M. et al. Avaliação do desempenho de genótipos de milho para consumo in natura em Tangará da Serra - MT. Bioscience Journal, v.27, n.4, p.603-608, 2011. Available from: <seer.ufu.br/index.php/biosciencejournal/article/ viewFile/8247/7762>. Accessed: Aug. 14, 2015.

HALLAUER, A.R. et al. Quantitative genetics in maize breeding. New York: Springer, 2010. 664 p.

KOUTSIKA-SOTIRIOU, M.S.; KARAGOUNIS, C.H.A. Assessment of maize hybrids. Maydica, v.50. p.63-70, 2005. Available from: <maydica.org/articles/50_063.pdf>. Accessed: Jul. 16, 2015.

LIMA, M. et al. Inbreeding depression in Brazilian populations of maize (Zea mays L.). Maydica, v.29, p.203-215, 1984.

MATOS, E.H.D.S.F. Cultivo do milho verde. Brasília: Universidade Nacional de Brasília. 2007. 24p.

SCAPIM, C.A. et al. Componentes genéticos de médias e depressão por endogamia em populações de milho pipoca. Ciência Rural, v.36. n.1. p.36-41, 2006. Available from: <http://www. scielo.br/pdf/cr/v36n1/a06v36n1.pdf>. Accessed: Apr. 22, 2015. doi: 10.1590/S0103-84782006000100006.

SENHORINHO, H.J.C. et al. Combining abilities and inbreeding depression in commercial maize hybrids. Semina, v.36, p.4133-4149, 2015. Available from: <dx.doi.org/10.5433/16790359.2015v36n6Supl2p4133>. Accessed: Apr. 25, 2015. doi: 10.5433/1679-0359.2015v36n6Supl2p4133.

SOUZA NETO, I.L. et al. Análise dialélica e depressão endogâmica de híbridos forrageiros de milho para características agronômicas e de qualidade bromatológica. Bragantia, v.74, n.1, p.42-49, 2015. Available from: $<$ http://www.scielo.br/pdf/brag/v74n1/0006-8705brag-74-1-42.pdf $>$. Accessed: Jun. 10, 2015. doi: 10.1590/16784499.0315 .

VENCOVSKY, R.; BARRIGA, P. Genética biométrica no fitomelhoramento. Ribeirão Preto: [S.ed.], 1992. 496p. 